\title{
RESEARCH ON THE INFLUENCING FACTORS OF CHINESE FAMILY BUSINESS'S SUCCESSION FROM THE PERSPECTIVE OF RE-CREATION
}

\author{
Li Qi* \\ Universitas Pendidikan Indonesia \\ Ratih Hurriyati \\ Universitas Pendidikan Indonesia \\ H Disman \\ Universitas Pendidikan Indonesia \\ Mohammad Ali \\ Universitas Pendidikan Indonesia
}

\begin{abstract}
Under the background of great changes in China's economic environment, a large number of small and medium-sized family businesses are in urgent need of transformation and upgrading that entering the channel of re-creation. For the family business, the successor signifies the future development direction and growth trend of the business. The inter-generational succession of the family business is a multistage evolution process influenced by many factors. In the specific succession practice of family businesses, the influence of the succession of family businesses is analyzed from the perspective of re-creation in combination with the actual situation. Based on the theory analysis on influencing factors of family business's succession and the way of the questionnaire and factor analysis measure, the research had found and explained the major influencing factors of Chinese family business's succession, namely, relationship, successor, creator, re-creation, organization, environment. It provided a reference on the inter-generational succession of Chinese family businesses from the perspective of re-creation.
\end{abstract}

Keywords: Quantitative Research, Family Business, Succession, Re-Creation, Influencing Factors.

Received: 10 September 2019

Accepted: 31 December 2020

https://doi.org/10.33736/ijbs.3167.2021

\section{INTRODUCTION}

With the development of modern society, family business plays an important role in the world economy. Faced with the transformation challenge of the "new normal" of the economy, family

\footnotetext{
* Corresponding author: Doctoral candidate, Universitas Pendidikan Indonesia, Bandung \& Lecturer Neusoft Institute Guangdong, China. Email: liqi@nuit.edu.cn
} 
business creators must be sustainable innovation, enter the channel of re-creation and improve Chinese family business's Gene. The inter-generational succession is one of the most difficult challenges faced by family businesses in their continuous growth. It is not only the superficial transfer of positions, but also the continuation of resources such as family business, entrepreneurship and interpersonal network.

Business life cycle refers to the process from birth to growth, maturity, decline to death. This is a process that all businesses go through. Businesses at different stages of the life cycle are faced with different environments and conditions, and require different management behaviors that are compatible with the characteristics of the business's growth, so as to ensure the effectiveness of management. After a successful business, it already has a strong strength, and according to the objective law of development of things, if there is no change, the business will definitely decline. For businesses to continue to develop and achieve higher goals, only through fundamental transformation of businesses can they start to develop on a new platform. Re-creation is the process of internal reform for businesses to seek for further development after achieving rapid growth. Its essence is a strategic transformation of business at a certain stage of development and a revolutionary transformation in the process of business development. To develop, businesses must carry out re-creation which on the basis of the existing business. Especially for the second generation successors, re-creation is both a crisis challenge and a success opportunity, and it requires successors to complete the mission successfully through "creative succession". The entrepreneurial intention is the original embodiment of the entrepreneurial spirit. The entrepreneurial intention is the fundamental basis and starting point of all entrepreneurial activities. It is also the key to the entrepreneurial spirit. So, the succession of entrepreneurial spirit is more important than the succession of ownership and control right.

In the specific succession practice of family businesses, the influence of the succession of family businesses is analyzed from the perspective of re-creation in combination with the actual situation. The research has found and explained the major influencing factors of Chinese family business's succession from the perspective of re-creation, which based on the theory analysis on influencing factors of family business's succession and the way of the questionnaire and factor analysis measure.

\section{LITERATURE REVIEW}

A large number of follow-up studies of family business succession cases have found that the duration of succession is usually long, up to 15-20 years (Handler, 1989; Vancil, 1987; Ward \& Aronoff, 1990). More and more scholars are beginning to question the early view of events and believe that succession is not just a simple step to pass the scepter. Although it is impossible to accurately indicate the beginning and end of the succession, scholars agree that succession begins before the successor does not enter the enterprise and ends after the realization of the management and ownership of the enterprise (Handler, 1994). Longenecker and Schoen (1978) firstly proposed that family business succession is a long-term social process. As the research deepens, more and more scholars agree that family business succession is a long-term process of multi-stage evolution influenced by multiple factors (Churchill \& Hatten, 1987; Dou \& Jia, 2006; Handler, 1990; Longenecker \& Schoen, 1978; Vancil, 1987). Churchill and Hatten (1987), Gersick, Lansberg, Desjardins and Dunn (1999) and other scholars divided the specific stages of the family business 
succession process from different perspectives, and laid a solid foundation for the further study of succession research. On the basis of the dimension and stage identification of the family business succession process, scholars try to apply the relevant theories of sociology and psychology to the family business succession research to deepen the understanding of the succession process. Handler (1994) applies the theory of role transfer to qualitatively analyze the process of role adjustment between founders and next-generation family members in the process of succession. From the perspective of resource and knowledge, it analyzes how successors acquire the key knowledge and skills of predecessors in the process of succession. Davis, Schoorman and Donaldson (1997) used agency theory to explain the relationship between family business succession and corporate performance, and both represent the efforts to analyze the succession process from different perspectives.

Scholars' researches were increasingly focused on successors, especially the next generation of family members, and believes that their will, participation, and ability are crucial to the intergenerational transfer of power. Research by Dumas (1992) and Handler (1990) found that the tendency of competent and trustworthy successors to take over the business drives the succession, and the succession plan is likely to be promoted by the successor rather than the incumbent. The status and role of successors in the process of succession have been closely watched by the researchers. For family businesses, successors signify the future direction and growth trend of the company. Different candidates will bring different results. Once there are mistakes in decisionmaking, it may have a fatal impact on the survival and development of the company. Therefore, in the face of the choice of successors, the creators of family businesses need to consider various factors, weigh the pros and cons and make the most correct choices.

\section{$2.1 \quad$ Creator}

The intention of the creator to leave. The creators have invested a lot of money and feelings to family business, and for them, family businesses are part of life. There is no doubt that businesses have an important position in their creators. As a result, we often find that many old entrepreneurs are still active in the first line of business and they are reluctant to leave. As long as physical conditions permit, they will still be active in family business management activities and continue to control ownership and management rights in their own hands. In addition, they believe that inheritance will bring about the loss of management power, social status and reputation, thus creating anxiety and reluctance to implement the inheritance plan (Handler, 1990; Lansberg, 1988). Sharma and Irving (2005) asserted that in the study of the factors of the family business succession, that creators do not want to let go which frequency is the highest.

The personality and requirement of the creator. Creators are good at empowering and handing over the power of decision-making to successors. This is very important for the cultivation and development of successors' leadership skills and is also essential for the successful succession of family businesses (Handler, 1990). However, they often have a sense of mystery and intuition, unaccustomed to authorization, and even some constraints, such as distrust, doing things by themselves. Therefore, it is equally important for creators to have a high degree of trust, positive guidance, good communication and knowledge sharing on the ability and strength of successors.

Entrepreneurship. The culture of a family business is often the spiritual culture of the first generation of creators. The entrepreneurial intention is the original embodiment of the 
entrepreneurial spirit. The entrepreneurial intention is the fundamental basis and starting point of all entrepreneurial activities. It is also the key to the entrepreneurial spirit. So, the succession of entrepreneurial spirit is more important than the succession of ownership and control right. The growth environment and social background of the creator and successor of family business are very different. The two generations of the father and son have different opinions on corporate culture, values and management norms. In China, the first generation of family business leaders are generally low-educated, while most of their offspring have a good educational background, so they have a systematic and in-depth understanding of new knowledge, new technologies, organizational structure and management models (Chu \& Li, 2003). And vigorously advocate the integration of modern management into the family business, changing the previous empirical management model. However, the succession and continuation of the core culture and management system of the enterprise to a certain extent is of great significance for ensuring the stability and coherence of the enterprise. Finding the point of convergence between culture and system between the two generations of father and son means that the creator can really decentralize and hand over the enterprise to the successor.

\subsection{Successor}

The aspiration of the successor. "Follow the father's business" is often the preferred succession model for family businesses, and it is also a necessary prerequisite for the business to continue to succeed in the form of family businesses. Therefore, the succession interest and willingness of the children of entrepreneurs have a great influence on whether this problem can be effectively solved. In China, there is a common phenomenon that children are not willing to take over the family business, and the expected return of the successor on the family business also affects the willingness to take over to some extent. Rewards in terms of work pleasure, honor and material status are favorable factors to attract successors to take over the family business. Material rewards given by parents are the driving force for their children to join the family business. Handler (1994) shows that the better the opportunities in the family business and the successor's personal career needs, personality, and life cycle, the smoother the succession process. From another perspective, the higher the satisfaction of the successor to the company, the more energy will be invested, the higher the enthusiasm for work, and the stronger the sense of responsibility. At the same time, there will be a unique sense of identity that it is worthy for family business.

The ability of the successor. Most empirical studies have shown that successors' education level, management ability, interpersonal network relationship and moral quality are positively related to smooth succession, and they can help successors to obtain credibility and legitimacy to a large extent. Goldberg (1996) believed that the level of education of successors is related to effective succession. King's empirical research found that the potential of successors has a significant impact on corporate performance after three years of succession. Miller pointed out that the lack of competence of successors is the root cause of failure, and strong physical fitness and good psychological quality contribute to successful succession. The development of the successors and the preparation of the leadership role are one of the most important factors influencing the success of the family business. In a study of family businesses that failed in the United States, BretonMiller, Miller and Steier (2004) found that $45 \%$ of the failures of succession were rooted in the inability of the successors to assume leadership roles. Therefore, educating or training the successors to help them acquire knowledge and improve their ability to gain recognition and orthodoxy is an important way and means to promote the success of the family business. 
The preparation of the successor. The degree of preparation is mainly related to internal career development and external work experience. Early contact with the business can make the successors more familiar with the company's culture, values and employees, which also cultivate and develop the capabilities required by the business. The internal career development of the enterprise, especially the grassroots work experience, is conducive to strengthening the successor's recognition of the company's core values and family culture, helping the successor to establish a good network of interpersonal relationships, establishing the necessary entrepreneurial prestige, and in heterogeneous resources and the transfer of knowledge has also played an important role (Barach \& Gantisky, 1995). In addition, successors can build relationships and trust through successful job promotion. The work experience of successors starting from the grassroots level and gradually being promoted has a positive impact on the performance after succession (Fiegener, 1996). Goldberg's (1996) study also shows that effective successors have longer family business work experience than ineffective successors. External work experience helps to improve the knowledge reserve, identity and credibility of successors, and accumulate management knowledge and practical experience. None of the successors with external work experience regretted it, and those who did not have external work experience would like to have a similar experience. Family business successors that achieve successful succession have a much richer external work experience than successors of family businesses that fail to succession.

\subsection{Relationship}

The relationship between creator and successor. The inter-generational succession of family business is closely related to the current situation of the relationship between family and business, especially the relationship between creators and successors. The relationship between the two includes mutual trust, Shared vision, cooperation and father-son relationship. Because family business creators have a long time to work, they have a large number of heterogeneity or tacit recognition related to the business. The effectiveness of this cognition and inter-generational transfer of social network has an important impact on the performance of the next generation. Studies by Handler (1990), Goldberg (1996) and Lansberg (1988) have shown that the quality of the relationship between the creator and the successor is significantly positively correlated with the success of the family business. Successors often regard the trust and respect of creators as their recognition and support. The communication between father and son on the world view, outlook on life, values, corporate, etc. is an important way to establish a harmonious relationship between the creators and the successor.

The relationship between family members. Compared with non-family businesses, the pursuit of harmonious family relationships by family members sometimes exceeds the desire for profit (Churchill \& Hatten, 1987; Handler, 1990). Especially in China, the "home culture" based on "Family harmony makes everything", the harmonious relationship between family members can produce strong centripetal force and cohesion, so that they can work together to solve various problems (Chu \& Luo, 2001). Relevant studies have also found that harmonious relationship has a good promotion effect on communication, understanding and trust among family members, which will also have a positive impact on successful succession. The degree of harmony among family members has a significant impact on the smoothness of the succession process. Among that, the relationship between family members includes different dimensions such as the relationship between descendants, the relationship between descendants and predecessors, and the relationship between creator and their spouses. 
The relationship between successors and non-family members. Non-family members include nonfamily shareholders, middle and senior managers and employees. The inter-generational succession of family business is accompanied by power changes and personnel transfers. This structural change will bring many uncertainties, which are not only related to family members, but also related to non-family members. If the problems arising in the process of change are not handled properly, serious conflicts and contradictions are likely to arise, hindering the smooth progress of succession and even leading to the decline and fall of family businesses. Therefore, successors should not only be recognized by entrepreneurs and other family members, but more importantly, they should be supported by important groups such as entrepreneur veterans, nonfamily shareholders and enterprise employees.

\subsection{Organization}

Succession plan. The inter-generational succession of family business is a dynamic and complex process. As an important rule and guarantee of this process, the succession plan plays a key role in the success of succession. Most young family businesses rely too much on the knowledge, experience and relationships of the first generation of creators, and the absence of succession plans leads to the loss of these important intangible management resources. Given the complexity of the family business's inter-generational succession process, pre-planned management is critical to the success of the business (Handler, 1990; Lansberg, 1988; Sharma, Chrisman, Pablo \& Chua, 2001). Especially in the case of the sudden death of the creator, such absence will largely lead to the upheaval of power structure, which will intensify the conflicts between the children of entrepreneurs and other family members, and cause problems in strategic decision-making and finance. For example, studies by Christensen (1953) have shown that family businesses that have established succession plans and communicated with key stakeholder groups are more profitable than those that do not have a plan. In reality, the vast majority of family businesses that make succession plans do not treat it as an important strategic decision, which is also the direct reason for frequent failures in succession.

Common vision. Common vision is the third discipline mentioned by Peter M. Senge in "The Fifth Discipline". He believes that the common vision of a team can help an organization cultivate the initiative and sincere dedication and devotion of its members. Having a highly consistent common vision and working together towards this ultimate goal have actively promoted the realization of the successful succession. Lansberg and Astrachan (1994) believe that the vision of the future of the company is the driving force in the succession process, which effectively matches the wishes of generations and plays an important role in attracting children to the family business. Dyer (1986) stressed that, in order to achieve successful succession, the family must have a fair and Shared view. They must form "high-level goal" that everyone agrees on and strives for. Goals that bind the family together. If the common vision of the successor and the family business is highly consistent, it will be easier to get the recognition and support of the creator, entrepreneur veterans and employees of the enterprise, which is conducive to the realization of successful succession. The establishment and persistence of the common vision is the driving force for the healthy and rapid development of family businesses and is conducive to improving the success rate of succession.

Board of directors. From the perspective of law, the protection of the legitimate rights and interests of shareholders is the responsibility of the board of directors. For the family business, the board of 
directors plays a broader role in both the family and business systems. Many scholars emphasized the importance of the board of directors, they believe that a well designed, clear responsibilities, including external independent directors of the board, can help the creators overcome the psychological obstacles in the process of succession and guide the smooth implementation of the succession plan. It is also possible to supervise the entire handover process in real time and, if necessary, to use the rights and obligations to enforce the succession plan to protect the owner's rights (Barach \& Ganitsky, 1995; Churchill \& Hatten, 1987; Lansberg, 1988; Sharma et al., 2001). In addition, the board of directors can provide suggestions to the management to resolve various contradictions and conflicts in the process of succession and ensure a smooth transition.

At the same time, in Chinese Family businesses, the role of the Family council is not prominent enough (Cao, 2002). Even some Family businesses have not set up a Family council, which is often replaced by some other organizational forms. Therefore, it will not be discussed as a separate influencing factor.

\subsection{Environment}

Re-creation stage. Under the background of great changes in China's economic environment, a large number of small and medium-sized family businesses are in urgent need of transformation and upgrading and entering the channel of re-creation. Re-creation is no longer for survival, but for an ecological creation. Establishing a modern knowledge industry and carrying out scientific knowledge operations are the core links of re-creation. And that can help to cultivate entrepreneurship of successors. Entrepreneurship is one of the most scarce resources of family business. The realization of inter-generational transmission of entrepreneurship is directly related to the success or failure of family business.

Creators sets up an example for their successors to start a business through the process of recreation and sends them a message full of crisis. At the same time, it is also possible to set an example for other elders in family business through the gradual decentralization of the process of re-creation, so that they also realize that it is time for the business to let new leaders take over, reducing the psychological impact of the real implementation stage and winning wider support. The way of succession by re-creation is a precautionary move. Through the process, the power transfer is gradual and smooth $(\mathrm{Li}, 2003)$. Especially for the second-generation successors, recreation is both a crisis challenge and a success opportunity, and it requires successors to complete the mission successfully through "creative succession". So, the succession of entrepreneurial spirit is more important than the succession of ownership and control right.

Industry background. The degree of competition varies according to the industry in which the family business is located, and the abilities and qualities of the successors may vary. Bruno et al. found that industries with less competitive intensity have lower requirements for successors, so creators, successors and other family members have enough time to adapt to changes in roles, and the probability of successful succession increases. Industries with higher competition intensity also have higher requirements on the ability of successors. Once the corresponding standards are not met, it is likely to fail in succession and even hinder the long-term development of enterprises. The evolution path of the industry will not only affect the type of leader of the successor of the family business, but also have a certain impact on the training method of the successor (Churchill \& Hatten, 1987). For family businesses in traditional industries, because the industry is stable, the 
enterprise does not need too much change will be able to adapt to the demand of the development, and career development within the enterprise to a large extent can effectively for a long time, after appropriate training and experience for the next generation of family members the possibility of a qualified leader will also be greatly increased. If family businesses are exposed to rapidly changing markets and have to make frequent adjustments to adapt to a competitive environment, training by a competitive organization or enterprise in the relevant industry may be more effective.

Society background. Family business is deeply rooted in social environment and generations succession is a long process of social. Therefore, family business succession of two generations is bound to be affected by many factors just like the Confucian culture, laws and regulations, moral ethics and clan beliefs. So, the relationship between blood, kinship, geography and so on becomes the most direct standard for measuring the trust system. For example, in terms of equity allocation, there is hardly any joint ownership by children in American family businesses, but this phenomenon is very common in Asia and Latin America (Stavrou,1998). In the selection criteria of successors, external work experience plays an important role in the selection criteria of family enterprises in the United States, while it is generally not valued in Portugal. Therefore, in the study of inter-generational succession of family businesses, cultural differences are a factor that must be paid attention to. China's special "family culture", economic environment, moral norms and legal environment, will inevitably have a direct or indirect impact on the inter-generational succession of family businesses.

\subsection{Reviews}

In the study of family business succession, the influencing factors and mechanism of successful succession are the most popular research topics. It is important that the system understands the antecedent variables of successful succession have a strong practical significance for the continued growth of family businesses, and also contribute to the further understanding of the family business's succession dynamics and complexity. However, due to different selection criteria and different analysis levels, the existing research on the factors affecting the succession of family business is relatively fragmented, lacking systematicity, and the inheritability between them is not strong. In addition, large number of family businesses are in urgent need of transformation and upgrading that entering the channel of re-creation. Dou and Jia (2006), on the basis of a comprehensive summary of the methods of family business definition, believed that scholars had reached a preliminary consensus on the research of the evaluation of succession results. They also affirmed the research ideas to evaluate successful succession from the two dimensions of succession process satisfaction and succession effect. And during the research, the subjects of this study are Chinese family businesses. Based on the analysis framework of the influencing factors on the family business's succession proposed by Dou and Jia (2006). This paper divides the influencing factors of succession from the perspective of re-creation into five levels: creator, successor, relationship, organization and environment. Five analysis levels try to sort out the existing research results.

There are a number of specific indicators through the analysis and summary of the above factors influencing, such as shown in Table 1: 
Table 1: Indicator scales for the influencing factors of Chinese family business's succession from the perspective of re-creation

\begin{tabular}{|c|c|c|c|}
\hline $\begin{array}{l}\text { Influencing } \\
\text { factors }\end{array}$ & \multicolumn{3}{|c|}{ Specific indicators } \\
\hline Creator & $\begin{array}{l}\text { (1)The intention of the } \\
\text { creator to leave }\end{array}$ & $\begin{array}{l}\text { (2) The personality and } \\
\text { requirement of the creator }\end{array}$ & (3)Entrepreneurship \\
\hline Successor & $\begin{array}{l}\text { (1)The aspiration of the } \\
\text { successor }\end{array}$ & (2) The ability of the successor & $\begin{array}{l}\text { (3) The preparation of the } \\
\text { successor }\end{array}$ \\
\hline Relationship & $\begin{array}{l}\text { (1)The relationship } \\
\text { between creator and } \\
\text { successor }\end{array}$ & $\begin{array}{l}\text { (2) The relationship between } \\
\text { family members }\end{array}$ & $\begin{array}{l}\text { (3) The relationship between } \\
\text { successors and non-family } \\
\text { members }\end{array}$ \\
\hline Organization & (1) Succession plan & (2) Common vision & (3) Board of directors \\
\hline Environment & (1) Re-creation stage & (2) Industry background & (3) Society background \\
\hline
\end{tabular}

\section{QUANTITATIVE RESEARCH}

\subsection{Survey and questionnaire design}

The method of this study is empirical research, and questionnaire survey is mainly used to collect the attitudes of the research objects. During the research, the subjects of this study are Chinese family businesses in China and Southeast Asia. Mainly under the background of re-creation, family businesses that are undergoing or planning the inter-generational succession. In the aspect of questionnaire design, the questionnaire of this study is mainly designed by the combination of indepth interview and literature search. The scale is constructed according to the characteristics of the research objects. The SPSS statistical software is used to conduct statistical tests of reliability and validity. The formal survey is conducted on the basis of the qualified predictive test scale. After formal survey and data collection, statistical methods combining descriptive statistical analysis and exploratory factor analysis are mainly used. By using factor analysis, the factors influencing the succession of Chinese family businesses in the re-creation stage were corrected, and the weights of common factors are determined.

The descriptive statistics analyzed the basic data and distribution of the sample, calculate the mean and the standard deviation, and analyzed the concentration and discrete trend of the sample. In this study, questionnaires were sent to the respondents by e-mail and face-to-face interviews. A total of 235 questionnaires were distributed, a total of 182 were recovered and the overall recovery rate was $77.45 \%$. By sorting out, the invalid questionnaire and interviewees were unfamiliar with creators or successors were excluded, and finally obtained 156 of the effective questionnaires. The effective recovery rate was $85.71 \%$. Questions in the questionnaire according to Table 1 , a total of 15 questions, using Likert's five-point scale from "very important" to "not very important", and it is need to recognized the extent of each indicator. Their corresponding assigned a score from 5 points, successive reduction.

\subsection{Descriptive statistics}

From a gender perspective, there are 132 men (84.62\%) and 24 women (15.38\%) among the sample of surveyed. The persons surveyed included entrepreneurs, children of entrepreneurs and senior managers of businesses. This distribution presents the basic characteristics of the management 
talent team, which is also quite common in various types of enterprises. In terms of age distribution, there are 30 people aged 41-45, accounting for $19.23 \%$; 69 people aged 46-50, accounting for $44.23 \%$; and 57 people over 51 years old, accounting for $36.54 \%$. From the perspective of academic qualifications, there are 35 high school/technical secondary school academic qualifications, 48 junior college graduates, 44 bachelor degrees, and 29 master degrees or above, accounting for $22.43 \%, 30.77 \%, 28.21 \%$, and $18.59 \%$ respectively.

By using SPSS statistical software, the mean and standard deviation of the 15 measurement indicators in this study were calculated. The calculation results are shown in table 2 . It can be learned from the table:

From the average of each index, the average level of the influencing factors is above medium. From the standard deviation score, the dispersion degree of each factor is not high, indicating that there is little difference among individuals in this sample.

The highest score is the Q3 (The relationship between creator and successor), which shows that the relationship between creator and successor is very important. And then Q9 (The aspiration of the successor), Q6 (The intention of the creator to leave), Q12 (Succession plan), etc., and other indexes have a general performance.

Table 2: The average and standard deviation of the research index

\begin{tabular}{|c|c|c|c|c|c|}
\hline Index & Sample N & Min & Max & Mean & Std. Deviation \\
\hline $\begin{array}{l}\text { Personality and requirement of the } \\
\text { creator }\end{array}$ & 156 & 3 & 5 & 4.5824 & .56725 \\
\hline Ability of the successor & 156 & 3 & 5 & 4.4375 & .58525 \\
\hline $\begin{array}{l}\text { Relationship between creator and } \\
\text { successor }\end{array}$ & 156 & 3 & 5 & 4.7831 & .50358 \\
\hline Common vision & 156 & 2 & 5 & 3.6688 & .74124 \\
\hline Re-creation stage & 156 & 3 & 5 & 4.0316 & .72383 \\
\hline The intention of the creator to leave & 156 & 3 & 5 & 4.5938 & .56885 \\
\hline Entrepreneurship & 156 & 3 & 5 & 4.1406 & 61137 \\
\hline Preparation of the successor & 156 & 3 & 5 & 4.1022 & .64851 \\
\hline Aspiration of the successor & 156 & 3 & 5 & 4.6875 & .51553 \\
\hline Relationship between family members & 156 & 3 & 5 & 4.1406 & .61137 \\
\hline $\begin{array}{l}\text { Relationship between successors and } \\
\text { non-family members }\end{array}$ & 156 & 3 & 5 & 4.2422 & .68443 \\
\hline Succession plan & 156 & 3 & 5 & 4.5313 & .54610 \\
\hline Board of directors & 156 & 2 & 5 & 4.0381 & .71335 \\
\hline Industry background & 156 & 3 & 5 & 3.9688 & 69229 \\
\hline Society background & 156 & 2 & 5 & 3.7500 & .65207 \\
\hline
\end{tabular}

\subsection{Validity \& Reliability Analysis}

According to the statistical methods of the data and the statistical results of the Likert attitude scale, reliability analyses as shown in Table 3. And the data analysis results show that the alpha values of each variable and factor are above 0.7 , which indicates that the data of the initial variables with higher reliability. 
Table 3: Variable Reliability Analysis Table

\begin{tabular}{lcc}
\hline \hline Variable & Item Number & Cronbach Alpha \\
\hline Creator & 3 & 0.824 \\
Successor & 3 & 0.782 \\
Relationship & 3 & 0.813 \\
Organization & 3 & 0.785 \\
Environment & 3 & 0.797 \\
\hline \hline
\end{tabular}

After KMO and Bartlett test, the results shown in Table 4. The observed value of Bartlett test is 572.968 , a great value, the corresponding significance probability is less than the significance level $\alpha$. It is considered that the correlation coefficient matrix is significantly different from the identity matrix, and the factor analysis is applicable. At the same time, the KMO value is 0.749 . According to the measure of the standard, we can see the original variables suitable for factor analysis.

Table 4: KMO and Bartlett Test

\begin{tabular}{ccc}
\hline \hline \multicolumn{2}{c}{ Kaiser-Meyer-Olkin Measure of Sampling Adequacy. } & .749 \\
\hline \multirow{3}{*}{ Bartlett's Test of Sphericity } & Approx. Chi-Square & 572.968 \\
& Df & 156 \\
& Sig. & .000 \\
\hline \hline
\end{tabular}

\subsection{Factor analysis}

\subsubsection{Data computing and processing}

In the process of factor analysis, the Principal Factor Analysis was used to extract the factors, and the factors were rotated according to the Varimax Rotation. The selection of the number of factors is based on the eigenvalue greater than 1 . The factor loading of the variable is greater than 0.5 as the standard, and the failure to meet the above requirements is discarded. The naming of the factors after categorization, in principle, if the categorized factors are the same as the original variables, they are named as the original variable names. And the different ones are renamed by the variables covered by the synthesis.

The results of data processing are shown in Table 5. It can be seen from the table that factor analysis on the 15 indicators that influence the succession of Chinese family business in the questionnaire, and six factors with the eigenvalue greater than 1 are extracted, and the variance contribution rate is $80.69 \%$. That is, 6 principal components contain $80.69 \%$ of the total amount of information provided by the original data and the results are ideal. At the same time, all questions have high loads on their respective factors, while the loads on other factors is very low, indicating that the questionnaire has good validity. 
Table 5: Rotated factor load matrix

\begin{tabular}{|c|c|c|c|c|c|c|}
\hline \multirow{2}{*}{ Indicators } & \multicolumn{6}{|c|}{ Factors } \\
\hline & 1 & 2 & 3 & 4 & 5 & 6 \\
\hline $\begin{array}{l}\text { Q03 The relationship between creator and } \\
\text { successor }\end{array}$ & .842 & & & & & \\
\hline $\begin{array}{l}\text { Q10 The relationship between family } \\
\text { Members }\end{array}$ & .761 & & & & & \\
\hline $\begin{array}{l}\text { Q11 The relationship between successors } \\
\text { and non-family members }\end{array}$ & .715 & & & & & \\
\hline Q09 The aspiration of the successor & & .859 & & & & \\
\hline Q02 The ability of the successor & & .809 & & & & \\
\hline Q08 The preparation of the successor & & .683 & & & & \\
\hline Q06 The intention of the creator to leave & & & .824 & & & \\
\hline $\begin{array}{l}\text { Q01 The personality and requirement of } \\
\text { the creator }\end{array}$ & & & .653 & & & \\
\hline Q07 Entrepreneurship & & & .507 & & & \\
\hline Q12 Succession plan & & & & .723 & & \\
\hline Q05 Re-creation stage & & & & .553 & & \\
\hline Q04 Common vision & & & & & 698 & \\
\hline Q13 Board of directors & & & & & .577 & \\
\hline Q14 Industry background & & & & & & .591 \\
\hline Q15 Society background & & & & & & .560 \\
\hline
\end{tabular}

\subsubsection{Factors named}

The first common factor contains three indicator variables, Q3 (The relationship between creator and successor), Q10 (The relationship between family members), Q11 (The relationship between successors and non-family members). These indicators are parts of the relationship; it can be named as Relationship.

The second common factor contains three indicator variables, Q9 (The aspiration of the successor), Q2 (The ability of the successor), Q8 (The preparation of the successor). These indicators are parts of the successor; it can be named as Successor.

The third common factor contains three indicator variables, Q6 (The intention of the creator to leave), Q1 (The personality and requirement of the creator), Q7 (Entrepreneurship). These indicators are parts of the creator; so it can be named as Creator.

The forth common factor contains two indicator variables, Q12 (Succession plan), Q5 (Re-creation stage). The two indicators are closely related to re-creation; so it can be named as Re-creation.

The fifth common factor contains two indicator variables, Q4 (Common vision), Q13 (Board of directors). The two indicators are closely related to organization; so it can be named as Organization.

The sixth common factor contains three indicator variables, Q14 (Industry background), Q15 (Society background). The two indicators are parts of environment; so it can be named as Environment. 


\section{RESULTS}

It can be seen from the above analysis, from the perspective of re-creation the influencing factors of Chinese family business's succession that can be divided into the following six ways: Relationship (The relationship between creator and successor, The relationship between family members, The relationship between successors and non-family members); Successor (The aspiration of the successor, The ability of the successor, The preparation of the successor); Creator (The intention of the creator to leave, The personality and requirement of the creator, Entrepreneurship ); Re-creation (Succession plan, Re-creation stage); Organization (Common vision, Board of directors); Environment (Industry background, Society background).

The total variance contribution rate of six common factors is $80.69 \%$, which represents the impact of Chinese family business's succession from the perspective of re-creation. For each common factor, variance contribution rate represents the relative importance of common factors, the greater the variance contribution rate, which factors are relatively more important. According to the total variance contribution rate, it can be calculated for each of the factors. As shown in Table 6 .

Table 6: Weight percentage of common factor

\begin{tabular}{ccc}
\hline \hline $\begin{array}{c}\text { Common } \\
\text { factor }\end{array}$ & Common factor name & Weight percentage \\
\hline F 1 & Relationship & 21.07 \\
F 2 & Successor & 18.12 \\
F 3 & Creator & 17.23 \\
F 4 & Re-creation & 15.01 \\
F 5 & Organization & 14.52 \\
F 6 & Environment & 14.05 \\
\hline \hline
\end{tabular}

\section{DISCUSSION}

The objectives of this study as follows: To make out influencing factors of Chinese family business's succession from the perspective of re-creation.

In the specific succession practice of family businesses, the influence of the succession of family businesses is analyzed from the perspective of re-creation in combination with the actual situation. From the results, the finding of this study is the factor "re-creator", the new influence factor. From the literature review, there are only five key factors, so this study provides a reference on the academic research and practical management in family business's succession.

\section{CONCLUSION}

Quantitative studies have shown that from the perspective of re-creation, the succession of Chinese family business are six aspects of the main influencing factors, namely, relationship, successor, creator, re-creation, organization, environment. Among them, the importance of the first four factors accounted for the total weight of $71.43 \%$. So they are the key factors influencing, it provided a reference on the inter-generational succession of Chinese family business under the 
background of great changes in China's economic environment. From the perspective of re-creation, this study made guidance for improving the better understanding of Chinese family business' succession on these important factors, and to find targeted preventive or solution measures to promote the realization of successful succession.

\section{LIMITATION}

In family businesses, the characteristics and difficulties of the process of re-creation are different in the different stage of re-creation. So, as an influencing factor, it's changing in the process of recreation and succession. Further research is necessary for the influencing factor of re-creator. From the perspective of re-creation, we need to study more to ensure that the succession of the family business is successful.

\section{ACKNOWLEDGEMENT}

This research was supported by the China-Southeastern Asia family business research center in China.

\section{REFERENCES}

Barach, J. A., \& Ganitsky, J. B. (1995). Successful succession in family business. Family Business Review, 8(2), 131-155.

Breton-Miller, I. L., Miller, D., \& Steier, L. (2004). Towards an integrative model of effective FOB succession. Entrepreneurship Theory \& Practice, 29(2), 305-328.

Cao, D. J. (2002). Several theoretical problems of family business research. Financial science, 2(6), 49-55.

Christensen, C. (1953). Management succession in small and growing enterprises. Boston: Harvard Business School Press.

Chu, X. P., \& Li, H. Z. (2003). The integration of family business growth and social capital. Economic theory and management, 5(6), 49-53.

Chu, X. P., \& Luo, T. J. (2001). The comparison and implications of the trust and the evolution of the Chinese and American family businesses. Academic Research, 5(5), 50-55.

Churchill, N. C., \& Hatten, K. J. (1987). Non-Market-Based transfers of wealth and power: A research framework for family businesses. Journal of Small Business, 11(3), 51-64.

Davis, J. H., Schoorman, F. D., \& Donaldson, L. (1997). Towards a stewardship theory of management. Academy of Management Review, 22(1), 20-47.

Dou, J. S., \& Jia, S. H. (2006). Research review of the influence factors on family business succession. Foreign economy and management, 6(9), 52-58.

Dumas, C. (1992). Integrating the daughter into family business management. Entrepreneurship Theory and Practice, 16(2), 41-55.

Dyer, W. G. (1986). Cultural Change in Family Firms: Understanding and Managing Business and Family Transitions. San Francisco: Jossey-Bass Press. 
Fiegener, M. K. (1996). Passing on strategic vision. Journal of Small Business Management,34(3), 15-26.

Handler, W. C. (1989). Methodological issues and considerations in studying family businesses. Family Business Review, 2(3), 257-276.

Handler, W. C. (1990). Succession in family firms: a mutual role adjustment between entrepreneur and next-generation family members. Entrepreneurship: Theory \& Practice, 15(1), 37-51.

Handler, W. C. (1994). Succession in family business: A review of the research. Family Business Review, 7(2), 133-157.

Gersick, K. E., Lansberg, I., \& Desjardins, M., \& Dunn, B. (1999). Stages and transitions: Managing change in the family business. Family Business Review, 12(4), 287-297.

Goldberg, S. D. (1996). Effective successors in family-owned businesses: Significant elements. Family Business Review, 9(2), 185-197.

Lansberg, I. S. (1988). The succession conspiracy: Resistance to succession planning in first generation family firms. Family Business Review, 1(2), 119-143.

Lansberg, I. S., \& Astrachan, J. H. (1994). Influence of family relationships on succession planning and training: The importance of mediating factors. Family Business Review, 7(1), 39-59.

Li, X. C. (2003). Manager market failure and family business governance. Management World, 4(4), 41-53.

Longenecker, J. G., \& Schoen, J. E. (1978). Management of succession in the family business. Journal of small Business Management, 16(3), 1-6.

Sharma, P., Chrisman, J. J., Pablo, A. L., \& Chua, J. H. (2001). Determinants of initial satisfaction with the succession process in family firms: A conceptual model. Entrepreneurship Theory and Practice, 25(3), 17-35.

Sharma, P., \& Irving, P.G. (2005). Four bases of family business successor commitment: Antecedents and consequences. Entrepreneurship Theory and Practice, 30(1), 13-33.

Stavrou, E. T. (1998). A four factor model: A guide to planning next generation Involvement in the family firm. Family Business Review, 11(2), 135-142.

Vancil, R. F. (1987). Passing the baton: Management the process of CEO succession. Boston: Harvard Business School Press.

Ward, J. L., \& Aronoff, C. E. (1990). Trust gives you the advantage. Nation's Business, 79(8), 4245. 